\title{
Increasing the efficiency of crop production during sustainble soil cultivation based on the use of new biogenic preparations
}

\author{
V.T. Lobkov ${ }^{1, *}$, V.P. Naumkin ${ }^{1}$, N.A. Lopachev ${ }^{1}$, N.Yu. Sushenkova ${ }^{1}$, and S.Yu. Sorokina ${ }^{2}$ \\ ${ }^{1}$ Federal State Budgetary Educational Establishment of Higher Education "Orel State Agrarian \\ University named after N.V. Parakhin", Orel, Russia \\ ${ }^{2}$ Federal State Budgetary Scientific Institution "Federal Scientific Center of Legumes and Groat \\ Crops"
}

\begin{abstract}
The state of ecology in the world, and as a result, the requirements of the world community make agricultural producers turn to sustainable agriculture, which involves implementation of measures aimed at eliminating and preventing land degradation and greening agricultural production along with the biologization of agriculture. Sustainable agriculture is agriculture based on the competent use of the laws of nature, scientific achievements, focused on healing soil, reducing costs and improving quality of agricultural products. One of the directions of the land husbandry biologization is increasing the efficiency of basic fertilizers assimilation through leaf treatments with biogenic preparations of different nature (microbiological, growth-regulating, based on macro- and microelements, etc.). The possibility to increase the efficiency of agricultural crops cultivation with sustainable soil cultivation, such as flatcut and No-Till technology with the help of biogenic preparations, was studied. Preparations Strada N and Izagri N play a leading role in terms of the influence of biogenic preparations on the productivity. An improvement in product quality was observed when using biological preparations Strada N, Humat with microelements, Izagri N, Zerebra, Agro + Gumat. As a result, biogenic preparations with a high efficiency of simulating production process when using sustainable soil cultivation were established. The use of these preparations on grain crops can be a factor for increasing the efficiency of these types of soil cultivation, which will expand the area of application of this environmentally effective and sustainable method.
\end{abstract}

\section{Introduction}

The top-priority tasks of agriculture are to ensure economically efficient and environmentally friendly agricultural production based on optimization of the soil structure, restoration of its natural microbiological activity, and reduction of chemical load. Nowadays, competent use of the laws of nature, scientific achievements aimed at healing

\footnotetext{
${ }^{*}$ Corresponding author: v.lobckov2014@yandex.ru
} 
soil, reducing costs and improving the quality of agricultural products is not an opportunity, but a necessity for the society.

Large energy costs, accelerated humus mineralization, development of erosion and deflation processes, soil compaction, etc. are mainly associated with the intensive nature of soil cultivation [1-2]. The intention to reduce these negative manifestations, especially in terms of resource- and energy savings, is a typical feature of modern soil cultivation science, while minimization of soil cultivation is one of the main trends in the world agronomical science. Minimization means decreasing the tillage depth, exclusion of some techniques from the processing system, combination of several technological operations through the use of combined units, use of less energy- and resource-intensive techniques and methods, etc. $[3,4,6]$

One of the directions of sustainable minimized soil cultivation is the replacement of plowing with flat-cut cultivation. If using plowing the fuel consumption is $30-351 /$ ha, then when using flat-cut processing, it can be reduced to 5-7 1/ ha. Consequently, there is a decrease in the total energy costs. With flat-cut soil cultivation, the loss of the humus fund decreases, the intensity of erosion and deflation processes in comparison with moldboard cultivation decreases as well $[5,7]$.

When using flat-cut cultivation up to $65 \ldots 85 \%$ of stubble and other plant residues are remained on the soil surface, which entrap snow in winter well, and in spring, after it melts, they serve as a reliable mulching agent. As a result, the reserves of productive moisture before sowing spring crops and, accordingly, their yield are higher than with moldboard plowing.

However, flat-cut cultivation also has disadvantages. In particular, when it is applied, weed infestation of crops increases; conditions for preserving the rudiments of harmful objects are improved; due to the preservation of plant residues on the soil, it is difficult to create a good sowing layer; there is a differentiation (sharp separation) of the arable horizon layers in fertility. As a result, there is a shortage of harvest and insufficient effectiveness of this technique is observed.

Sustainable cultivation also includes No-Till, a method in which direct sowing is carried out into untilled soil. This method also involves preservation of stubble or crushed plant residues - mulch, in other words, on the soil surface.

With the introduction of No-Till, the process of restoring the biological activity of the soil is started. Non-symbiotic nitrogen-gathering bacteria, provided with sufficient nutrition, can bind from 60 to $400 \mathrm{~kg}$ of rate of application of nitrogen per year on different types of soil. Canadian studies (Lafon) revealed a tendency to increase the yield without the use of nitrogen fertilizers when switching to No-Till from $1.75 \mathrm{t} /$ ha (after 2 years) to $-2.8 \mathrm{t}$ / ha in 20 years. Long-term use of this system has also led to an increase in the protein content in grain [8].

In this work a study of the possibility to increase the efficiency of resource-saving methods of soil cultivation using biogenic preparations was carried out.

The purpose of the research is to provide high efficiency of sustainable soil cultivation based on the activation of the production process with the use of non-traditional physiologically active substances in crops.

To achieve it, the following tasks were solved:

- determining the effect of the preparations: Binoram; Biosil; Humate with microelements; Zerebro Agro; Izagri N; Microvit Standard; Reasil Zinc; Sapropel; Strada $\mathrm{N}$; Energen Aqua on the yield of agricultural crops against the background of the use of resource-saving tillage technologies;

- determining the impact of the use of biopreparations on the yield quality. 


\section{Conditions, materials and methods}

The study was carried out in the Central Black Earth Region of the Russian Federation: in the Orel district of the Orel region in 2017-2019 on the experimental fields of the Scientific and Educational Production Center "Integration" of the Federal State Budgetary Educational Establishment of Higher Education "Orel State Agrarian University named after N.V. Parakhin". It is based on the long-term stationary experience of the Department of Agriculture, Agrochemistry and Agrosoil Science in the study of soil cultivation technologies in the Orel district of the Orel region.

The relief of the site is leveled. The soil of the experimental plot is dark gray forest soil.

Year 2017 was characterized as a year with favorable weather conditions, but in the second half of the growing season there was an excessive amount of precipitation (191\% of the norm in July and $147 \%$ - in August), which caused lodging during the grain-filling period and, consequently, to the reduction in yields.

The climatic conditions of the growing season in 2018 in terms of temperature regime were marked by warm weather. During the entire growing season, the average air temperature exceeded the long-term average annual temperature by 1.1-4.00 $\mathrm{C}$, and the amount of precipitation was $70 \%$ of the long-term average annual amount.

The climatic conditions of the growing season of 2019 in terms of temperature were marked by warm weather. June was characterized by high temperatures. Excessive moisture was observed in May and July.

Characteristics of the preparations: The following preparations were selected to increase the activity of plant growth processes: Binoram; Biodux; Biosil; Humate with microelements; Zerebro Agro; Izagri N; Microvit Standard; Reasil Zinc; Strada N; Energen Aqua.

Binoram. The bacteria, included into the preparation, secrete indolyl-3-acetic acid, which has a growth-stimulating effect on plants. The drug suppresses pathogenic microflora, mainly lower fungi.

Biosil. The preparation is used as a growth regulator and an immunity inducer to a complex of fungal, bacterial and viral diseases.

Humate with microelements. The preparation is a fertilizer, a growth regulator, and a natural complexing agent, which increases the efficiency of fertilizer assimilation and neutralizes heavy metals and toxins.

Zerebra Agro. The active ingredient of the preparation is colloidal silver. A universal preparation, capable of being integrated into any plant protection and nutrition system, prevents plant diseases and enhances the action of fungicides.

Zerebra Agro + Humate. The active ingredients of the preparation are colloidal silver and humic acids.

Isagri $\mathbf{N}$. The fertilizer contains nitrogen in nitrate and general forms, as well as other substances and microelements, facilitating its effective assimilation by plants,.

Microvit Standard. The preparation contains a complex of chelated microelements.

Reasil Zn. The preparation has a positive effect on protein synthesis and control of moisture content. It regulates the production of auxins - hormones that determine the size of the leaf. It also increases the production of tryptophan, which regulates plant growth.

Strada N. It is highly concentrated suspension. The microelements enhance biochemical processes, promote rapid conversion of nitrogen into an organic form.

Energen Aqua. It is an organic and mineral fertilizer based on humic acids.

Biodux. It is a multipurpose plant growth regulator with immune stimulating properties. Its active ingredient is a complex of biologically active polyunsaturated acids of the lower soil fungus Mortierellaalpina. The preparation forms a non-specific, systemic, long-term 
(within 1-2 months) resistance (to fungi, bacteria, viruses) and activates growth and biological processes in plants.

Preparative form: liquid.

Culture, variety: In the experiment of 2017 oats of variety "Borets" were sown, in 2018 spring wheat of variety "Daria" and in 2019 soybean of variety "Lantsentnaya' were sown.

The experiment scheme: 12 options: 1. Strada N 2. Biosil 3. Binoram 4. Humate with microelements 5. Reasil 6. Sopropel 7. Izagri N 8. Energen Aqua 9. Zerebra Agro 10. Microvit 11. Zerebra Agro-Humate 12. Control. Three replications.

The placement of plots in the experiment is systematic. The experiment area is $1600 \mathrm{~m}^{2}$, accounting plot is $26 \mathrm{~m}^{2}$. The preparations were applied with an electric sprayer in the recommended doses in the tillering and heading phases, the consumption of preparations was 3.01 / ha, the consumption of the working solution was $3001 /$ ha.

The agrotechnical measures are typical for the cultivation area.

The determination of the biological yield and its structure was carried out according to the "Methodology of State Variety Testing of Agricultural Crops" (1972).

The statistical processing of the results was carried out according to B.A. Dospekhov (1985).

\section{Results and discussion}

The introduction of most of the preparations increased both the grain yield and its quality.

The influence of the studied factors on the productivity of oats was complex.

Table 1. Influence of biopreparations during flat-cut soil cultivation on oat productivity indicators, 2017.

\begin{tabular}{|l|l|c|c|c|c|}
\hline \multirow{2}{*}{ № } & \multicolumn{1}{|c|}{ Preparations } & \multicolumn{4}{c|}{ Oats grain yield, $\mathrm{t} / \mathrm{ha}$} \\
\cline { 3 - 6 } & & 2016 & 2017 & 2018 & Average \\
\hline 1. & Strada N & 1.1 & 1.1 & 1.09 & 1.1 \\
\hline 2. & Biosil & 1.08 & 1.05 & 1.05 & 1.08 \\
\hline 3. & Binoram & 1.09 & 1.08 & 1.08 & 1.08 \\
\hline 4. & $\begin{array}{l}\text { Humate with } \\
\text { microelements }\end{array}$ & 1.1 & 1.1 & 1.07 & 1.09 \\
\hline 5. & Reasil & 1.04 & 1.04 & 1.03 & 1.04 \\
\hline 6. & Sopropel & 1 & 1.1 & 1 & 1 \\
\hline 7. & Izagri N & 1.11 & 1.11 & 1.10 & 1.10 \\
\hline 8. & Energen Aqua + & 1.06 & 1.05 & 1.06 & 1.06 \\
\hline 9. & Zerebra Agro & 1.06 & 1.05 & 1.04 & 1.05 \\
\hline 10. & Microvit & 1.06 & 1.06 & & 1.06 \\
\hline 11. & Zerebra Agro+Humate & 1.09 & 1.10 & 1.09 & 1.09 \\
\hline 12. & Control & 0.99 & 1.01 & 0.91 & 0.97 \\
\hline 13. & Tillage & 1.09 & 1.11 & 1.08 & 1.09 \\
\hline & HCP05 & 0.011 & 0.008 & 0.007 & \\
\hline
\end{tabular}

According to the average annual indicators of oat productivity, the highest yield is observed when using such preparations as Strada N and Izagri N (1.1 t/ha). The minimum yield was observed when using Sopropel ( $1 \mathrm{t} / \mathrm{ha}$ ). Thus, when using biogenic preparations in the technology of grain crops cultivation based on flat-cut soil cultivation, the yield increases significantly.

An option with the classical moldboard processing was introduced into the study and the yield of oats in comparison with this option was analyzed. An interesting feature was revealed. The options with the use of biopreparations have approximately the same yield 
indicators as the option with plowing. This indicates that the shortage of yield during flatcut tillage in comparison with moldboard tillage can be largely compensated by activating the production process by using nontraditional preparations.

The results of the study with No-Till cultivation showed that the introduction of most of the preparations increased both the yield of oat grain and its quality on average by $10 \%$, Table 2.

Table 2. Influence of biogenic preparations with No-Till technology on oat productivity indicators, $\mathrm{t} / \mathrm{ha}, 2017$.

\begin{tabular}{|c|c|c|c|c|c|}
\hline \multirow{2}{*}{$\begin{array}{c}\text { № } \\
\text { of } \\
\text { option }\end{array}$} & Biopreparation & \multicolumn{3}{|c|}{ Plot } & \multirow{2}{*}{ Average } \\
\cline { 3 - 5 } & & 1 & 2 & 3 & \\
\cline { 3 - 5 } & & & & & \\
\hline 1 & Strada N & 1.42 & 1.42 & 1.408 & 1.42 \\
\hline 2 & Biosil & 1.296 & 1.26 & 1.26 & 1.27 \\
\hline 3 & Binoram & 1.308 & 1.296 & 1.296 & 1.29 \\
\hline 4 & Humate with microelements & 1.32 & 1.32 & 1.284 & 1.31 \\
\hline 5 & Reasil & 1.248 & 1.248 & 1.262 & 1.25 \\
\hline 6 & Sopropel & 1.2 & 1.32 & 1.2 & 1.2 \\
\hline 7 & Izagri N & 1.442 & 1.432 & 1.44 & 1.44 \\
\hline 8 & Energen Aqua + & 1.272 & 1.26 & 1.272 & 1.27 \\
\hline 9 & Zerebra Agro & 1.23 & 1.25 & 1.27 & 1.25 \\
\hline 10 & Microvit & 1.272 & 1.272 & 1.272 & 1.27 \\
\hline 11 & Zerebra Agro+Humate & 1.508 & 1.52 & 1.53 & 1.52 \\
\hline 12 & Control & 1.2 & 1.212 & 1.2 & 1.2 \\
\hline
\end{tabular}

Strada N (19\%), Izagri N (20\%), Zerebra Agro + Humat (by 26\%) became the most effective preparations for increasing oat yields when using No-Till. (Tab. 2).

For a complete study of the influence of biogenic preparations, we investigated the influence of biopreparations on such indicators of the crop quality as protein content in the grain, nature and size of the grains (Table 3).

Table 3. Influence of biogenic preparations on the indicators of the oat yield quality in relation to the indicators on the options of the experiment to the control, t/ha, 2017.

\begin{tabular}{|c|c|c|c|c|}
\hline \multirow{2}{*}{$\begin{array}{c}\text { № } \\
\text { of } \\
\text { option }\end{array}$} & Preparations & \multicolumn{3}{|c|}{ Indicators } \\
\cline { 3 - 5 } & Natural weight & Protein, \% & $\begin{array}{c}\text { Thousand grain } \\
\text { weight }\end{array}$ \\
\hline 1. & Strada N & 1.04 & 1.03 & 1.05 \\
\hline 2. & Biosil & 1.02 & 1.01 & 1.02 \\
\hline 3. & Binoram & 1.02 & 1.00 & 1.02 \\
\hline 4. & $\begin{array}{c}\text { Humate with } \\
\text { microelements }\end{array}$ & 1.03 & 1.03 & 1.03 \\
\hline 5. & Reasil & 1.02 & 1.01 & 1.02 \\
\hline 6. & Sopropel & 1.01 & 1.00 & 1.01 \\
\hline 7. & Izagri N & 1.05 & 1.03 & 1.05 \\
\hline 8. & Energen Aqua + & 1.02 & 1.02 & 1.02 \\
\hline 9. & Zerebra Agro & 1.00 & 1.01 & 1.00 \\
\hline 10. & Microvit & 1.02 & 1.02 & 1.03 \\
\hline 11. & Zerebra Agro+Humate & 1.02 & 1.03 & 1.02 \\
\hline 12. & Control & 1 & 1 & 1 \\
\hline
\end{tabular}

Analyzing the data from Table 2, the following results can be shown. The highest protein content in oat grain was found when using such biopreparations as: Strada N, 
Humate with microelements, Izagri N, Zerebra Agro + Humate $(1.03 \%$ in relation to the control). The minimum amount was observed when using Binoram and Sopropel (1\% in relation to the control). As a result of studying the data, we have identified the most effective biogenic preparations when used in flat-cut processing in relation to the protein.

The grain weight also depends on the effectiveness of biopreparations. Strada $\mathrm{N}$ and Izagri $\mathrm{N}$ (1.05 in relation to the control) were distinguished by the influence on the thousand grain weight. The minimum was noted for the biopreparation Zerebro Agro.

The same preparations, on average, increased the protein content in oat grain by $0.03 \%$; thousand grain weight from $0.02 \%$ (Zerebra Agro + Humate) to $0.05 \%$ (Strada $\mathrm{N}$ and Izagri $\mathrm{N})$; natural weight by of $0.04 \%$ on average with no-till.

In 2018 spring wheat of variety "Daria" was sown. The analysis of the effect of the biopreparations revealed the following:

Table 4. Influence of the introduction of nontraditional preparations for increasing the activity of plant growth processes with flat-cutting and No-Till technology on the yield of spring wheat grain, 2018.

\begin{tabular}{|c|c|c|c|c|c|c|c|}
\hline \multirow{3}{*}{$\begin{array}{l}\text { Seq. } \\
\text { No. }\end{array}$} & \multirow{3}{*}{ Preparation } & \multicolumn{3}{|c|}{ Flat-cut cultivation } & \multicolumn{3}{|c|}{ No-Till technology } \\
\hline & & \multirow{2}{*}{$\begin{array}{c}\text { Crop } \\
\text { productivity } \\
\text { t/ha }\end{array}$} & \multicolumn{2}{|c|}{ Increment } & \multirow{2}{*}{$\begin{array}{c}\text { Crop } \\
\text { productivity } \\
\mathrm{t} / \mathrm{ha}\end{array}$} & \multicolumn{2}{|c|}{ Increment } \\
\hline & & & $\mathrm{t} / \mathrm{ha}$ & $\%$ & & $\mathrm{t} / \mathrm{ha}$ & $\%$ \\
\hline 1. & Control & 2.3 & - & - & 2.12 & - & - \\
\hline 2. & Biosil & 2.64 & 0.34 & 14.68 & 2.44 & 0.32 & 15.09 \\
\hline 3. & $\begin{array}{l}\text { Zerebra } \\
\text { Agro+Huma } \\
\text { te }\end{array}$ & 2.68 & 0.38 & 16.81 & 2.47 & 0.35 & 16.51 \\
\hline 4. & Microvit & 2.56 & 0.26 & 11.3 & 2.35 & 0.23 & 10.85 \\
\hline 5. & Reasil & 2.57 & 0.27 & 11.87 & 2.39 & 0.27 & 12.74 \\
\hline 6. & $\begin{array}{l}\text { Energen } \\
\text { Aqua }+\end{array}$ & 2.65 & 0.35 & 15.1 & 2.42 & 0.3 & 14.15 \\
\hline 7. & Biodux & 2.67 & 0.37 & 16.07 & 2.45 & 0.33 & 15.57 \\
\hline 8. & Izagri $\mathrm{N}$ & 2.77 & 0.47 & 20.58 & 2.73 & 0.61 & 28.77 \\
\hline 9. & Binoram & 2.64 & 0.34 & 14.9 & 2.48 & 0.36 & 16.98 \\
\hline 10. & $\begin{array}{l}\text { Zerebra } \\
\text { Agro }\end{array}$ & 2.67 & 0.37 & 16.12 & 2.52 & 0.4 & 18.87 \\
\hline 11. & $\begin{array}{l}\text { Humate with } \\
\text { microelemen } \\
\text { ts }\end{array}$ & 2.65 & 0.35 & 15.39 & 2.38 & 0.26 & 12.26 \\
\hline 12. & Strada N & 2.9 & 0.6 & 26.02 & 2.87 & 0.75 & 35.38 \\
\hline
\end{tabular}

All the studied biopreparations had an effect on wheat yield and surpassed by $18 \%$ on average (table 4), which states the effectiveness of their use in crop rotation. The most effective preparations were Izagri $\mathrm{N}$ and Strada N, which increased yields by 28.77 and $35.38 \%$.

In 2019, soybeans of variety "Lanceolate" were sown. All the experimental options, treated with biogenic preparations, surpassed the control in yield (Table 5) both with NoTill and with flat-cut cultivation.

Table 5. The influence of the introduction of nontraditional preparations for increasing the activity of plant growth processes on the yield of soybeans with flat-cut soil cultivation and No-Till, $t$ / ha, 2019.

\begin{tabular}{|c|c|c|c|c|c|c|c|}
\hline \multirow{3}{*}{$\begin{array}{l}\text { Seq } \\
\dot{\text { No. }}\end{array}$} & \multirow{3}{*}{$\begin{array}{l}\text { Biogenetic } \\
\text { preparations }\end{array}$} & \multicolumn{3}{|c|}{ Flat-cut cultivation } & \multicolumn{3}{|c|}{ No-Till technology } \\
\hline & & \multirow{2}{*}{$\begin{array}{c}\text { Crop } \\
\text { productivity } \\
\text { t/ha }\end{array}$} & \multicolumn{2}{|c|}{ Increment } & \multirow{2}{*}{$\begin{array}{c}\text { Crop } \\
\text { productivity } \\
\text { t/ha }\end{array}$} & \multicolumn{2}{|c|}{ Increment } \\
\hline & & & $\mathrm{t} / \mathrm{ha}$ & $\%$ & & $\mathrm{t} / \mathrm{ha}$ & $\%$ \\
\hline
\end{tabular}




\begin{tabular}{|l|l|c|c|c|c|c|c|}
\hline 1 & Control & 2.34 & - & - & 2.05 & - & - \\
\hline 2 & Biosil & 2.74 & 0.4 & 17 & 2.47 & 0.42 & 20 \\
\hline 3 & Strada N & 2.95 & 0.61 & 26 & 2.78 & 0.73 & 36 \\
\hline 4 & Microvit & 2.71 & 0.37 & 16 & 2.38 & 0.33 & 16 \\
\hline 5 & Reasil & 2.7 & 0.36 & 15.4 & 2.45 & 0.40 & 19.7 \\
\hline 6 & $\begin{array}{l}\text { Energen } \\
\text { Aqua }+\end{array}$ & 2.6 & 0.26 & 11.2 & 2.32 & 0.27 & 13 \\
\hline 7 & Biodux & 2.81 & 0.47 & 20.1 & 2.55 & 0.5 & 24.6 \\
\hline 8 & $\begin{array}{l}\text { Zerebra } \\
\text { Agro }\end{array}$ & 2.86 & 0.52 & 22.1 & 2.56 & 0.51 & 24.9 \\
\hline 9 & Binoram & 2.58 & 0.24 & 10.4 & 2.32 & 0.28 & 13.5 \\
\hline 10 & Izagri N & 2.92 & 0.58 & 24.8 & 2.68 & 0.63 & 30.7 \\
\hline 11 & $\begin{array}{l}\text { Humate } \\
\text { with } \\
\text { microeleme } \\
\text { nts }\end{array}$ & 2.8 & 0.46 & 19.5 & 2.5 & 0.45 & 22.1 \\
\hline 12 & $\begin{array}{l}\text { Zerebra } \\
\text { Agro+Huma } \\
\text { te }\end{array}$ & 2.83 & 0.49 & 20.9 & 2.59 & 0.54 & 26.2 \\
\hline
\end{tabular}

All the preparations increased the yield of soybeans in comparison with the control group from 13-16\% (Microvit, Energen Aqua +) to 26-36\% (Zerebra Agro + Humate, Izagri N, Strada N).

\section{Conclusions}

One of the reasons for low competitiveness of domestic agricultural production is excessive costs of growing crops, backlog of scientific and technical weapon, application of outdated technologies [5].

New economical agricultural technologies, minimizing soil cultivation, will allow our country to compete with the world's leading agricultural producers.

Along with the advantages of sustainable soil cultivation, it has a number of disadvantages and limitations.

According to our research, the use of biogenic preparations in systems of sustainable soil cultivation in the Central Black Earth Region of the Russian Federation (by the example of the Orel region) is effective and can partially negate weakness of these systems. The introduced preparations both increase the yield of agricultural crops up to 10-36\%, and improve the grain quality: the content of protein, starch, etc. increases.

1. Such preparations as Strada N, Izagri N, a combination of Humate + Zerebra Agro increase the yield of oats, protein content, thousand grain weight and natural weight.

2. The introduction of the preparations that activate the processes of plant growth have shown efficiency in increasing the yield of spring wheat variety "Daria" on average by $18 \%$. Especially effective preparations are Izagri N and Strada N, which have increased the yields by 28 and $35 \%$, respectively, with no tillage and $20-26 \%$ with flat-cutting. The smallest increase was recorded, when preparation Microvit was used.

3. The introduced preparations increased the yield of soybeans: from 13-16\% (Energen Aqua +, Microvit) to $26-36 \%$ (Zerebra Agro + Humate, Izagri N, Strada N) with no-till and $20-26 \%$ with flat-cut cultivation.

4. The usage of the preparations on grain crops can be a factor for increasing the efficiency of sustainable cultivation, which will expand its application.

In general, it can be concluded that the use of new biogenic preparations for activating plant growth processes in the cultivation of agricultural crops is effective in sustainable soil cultivation. 


\section{References}

1. G.I. Bazdyrev, V.G. Loshakov, A.I. Puponin, Agriculture (Moscow, Kolos, 2000)

2. V.I. Kiryushin, Agr, 7, 3-6 (2013)

3. V.T. Lobkov, Agrochem, 10, 3-9 (2015)

4. V.T. Lobkov, V.V. Napolov, Agrochem, 9, 53-59 (2019)

5. V.T. Lobkov, A.S. Novikova, A.A. Zabrodkin, Gr ec of Russ, 2, $27-31$ (2013)

6. S.Yu. Sorokina, N.Yu. Sushenkova N.Yu, Ed, sc \& prod, 4, 61-62 (2016)

7. N.Yu. Sushenkova, S.Yu. Sorokina S.Yu, Bull of rur dev \& soc pol, 4 (12), 75-77 (2016)

8. Managing Nitrogen Like Your Profits Depend On It, https://www.notillfarmer.com/articles/1-managing-nitrogen-like-your-profits-depend-on-it 